\title{
Production of Erythropoietin by Liver Cells in Vivo and in Vitro
}

\author{
K.-U. ECKARDT, ${ }^{a}$ C. W. PUGH ${ }^{b}$ M. MEIER, ${ }^{a}$ C. C. TAN, ${ }^{b}$ \\ P. J. RATCLIFFE, ${ }^{b}$ AND A. KURTZ ${ }^{a}$ \\ ${ }^{a}$ Physiologisches Institut I \\ Universität Regensburg \\ Universitätsstrasse 31 \\ DW 8400 Regensburg, Germany \\ ${ }^{b}$ Institute of Molecular Medicine \\ John Radcliffe Hospital \\ Oxford, United Kingdom
}

The observation by Jacobson et al. in 1957 that the rise of plasma erythropoietin (EPO) levels in rodents is severely blunted following bilateral nephrectomy' has drawn attention to the important role of the kidneys in EPO formation. Continuing EPO production, however, albeit at a reduced level in adult anephric organisms, ${ }^{2,3}$ and the observation that anephric fetal and neonatal animals can produce as much EPO as unoperated ones ${ }^{4,5}$ provides evidence for the existence of extrarenal EPO formation. The investigation of EPO production in hepatectomized animals identified the liver as the primary extrarenal site of EPO synthesis. ${ }^{5.6}$ Much of the evidence, however, regarding the role of the liver for EPO production in vivo has been indirect inasmuch as it was drawn from experiments in organ-ablated animals and because the demonstration of EPO production mostly depended upon bioassays that were not specific for EPO or the use of antibodies raised against impure preparations of the hormone. More recently, direct demonstration of EPO gene expression, either by determination of EPO mRNA in tissue homogenates or by in situ hybridization on histological specimens, has allowed these studies to be extended and has not only confirmed a significant role of the liver in EPO production, but has also contributed to understanding of hepatic EPO formation at the cellular level. In this paper we will try to provide a brief overview of the knowledge that has accumulated and summarize some of our own work on EPO production by liver cells in vivo and in vitro.

\section{CONTRIBUTION OF THE LIVER TO EPO FORMATION IN VIVO}

In general, as in the kidneys, the major determinant of EPO production in the liver seems to be the oxygen content of blood. Thus, EPO hormone titers in anephric animals and hepatic EPO mRNA levels increase in response to reduction of either the oxygen carrying capacity or the oxygen saturation of blood.$^{7.8}$ Furthermore, isolated perfused livers release EPO upon hypoxic perfusion. ${ }^{9}$

The extent to which the oxygen-dependent production of EPO by the liver contributes to the total hormone production in the intact organism depends primarily on the developmental stage of the organism. A gradual "shift" of EPO production from liver to kidneys has been inferred from changes in the effect of nephrectomy and/or hepatectomy on EPO formation during development. The time of 
this transition was found to be variable among different species. Thus, in sheep, bilateral nephrectomy, already during late gestation, reduced EPO production, ${ }^{10}$ whereas in rats, nephrectomy had no effect on EPO production for up to two weeks after birth. ${ }^{6,11-13}$ In two studies, age-dependent changes in the contribution of liver and kidneys were demonstrated at the level of EPO mRNA. ${ }^{14,15}$ These studies have also pointed to considerable species differences; in mice the kidneys were found to contain the majority of total EPO mRNA during late gestation and during all stages of postnatal development, ${ }^{14}$ whereas in rats, in accordance with organ ablation studies, the liver was found to contribute more than $50 \%$ to the total amount of EPO mRNA up to four weeks of age ${ }^{15}$ (FIG. 1). Furthermore, we found in rats that although the predominance shifts from liver to kidneys beyond this age, the total amount of EPO mRNA in the liver does not decrease with age but remains fairly constant, becoming less significant, only because the accumula-

FIGURE 1. Hepatic proportion of the total (sum of renal and hepatic) EPO mRNA in rats of various ages that were exposed for 4 hours to normobaric hypoxia (mean $\pm \mathrm{SD}, \mathrm{n}=7$ for one-day old animals and 3 for all other groups). EPO mRNA was quantified by RNase protection. ${ }^{15}$

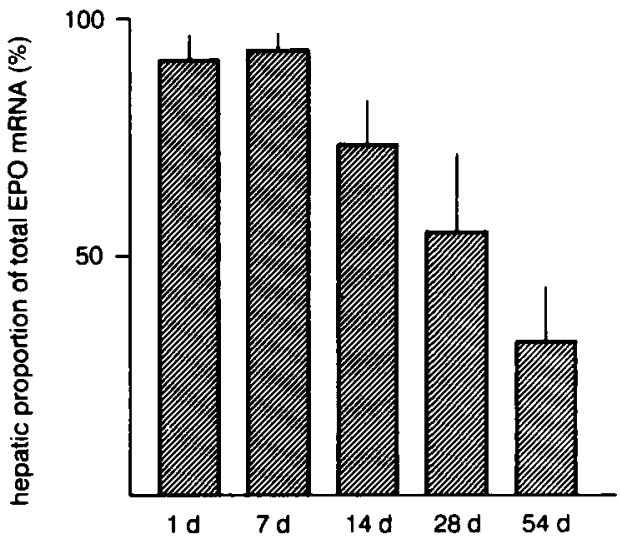

age

tion of EPO mRNA in kidneys increases progressively. ${ }^{15}$ The mechanisms preventing an increase in the production capacity for EPO in the liver, despite further growth of the organ, have not been resolved.

In adults the liver has generally been considered to contribute no more than about $15 \%$ of EPO production, inasmuch as serum EPO levels were found to be reduced to such low levels following bilateral nephrectomy. ${ }^{6,7,11,12}$ In intact animals, however, under conditions of severe hypoxic or anemic hypoxia, the liver was found to contain at least as much EPO mRNA as one kidney, thus contributing on average between one-third and one-half of the total ${ }^{8,15,16}$ Although these observations raise the possibility that hepatic EPO $\mathrm{mRNA}$ is not as efficiently translated into an increase in serum EPO levels as renal EPO mRNA, a more obvious explanation for this discrepancy became apparent when it was found that the 
expression of EPO mRNA in the liver is reduced following bilateral nephrectomy. ${ }^{15}$ Therefore, at least in adult rats, experiments in bilaterally nephrectomized animals have so far probably underestimated the contribution of the liver to EPO production. In humans the precise hepatic potential for EPO formation remains unknown. The anemia of chronic renal disease is characterized by inappropriately low serum EPO levels, ${ }^{17}$ clearly indicating that extrarenal sites do not fully compensate for loss of the renal production capacity of the hormone. On the other hand, under conditions of severe hypoxia, marked elevations of serum EPO can be found in patients with chronic renal failure, ${ }^{18,19}$ including anephric individuals, ${ }^{20}$ suggesting that these elevations reflect a considerable hepatic potential for EPO production. It might be possible that hepatic expression of EPO is impaired in some patients with chronic renal disease, as seen after bilateral nephrectomy in rodents. However, rats rendered chronically uremic by subtotal nephrectomy were found to become anemic, although the hepatic EPO mRNA response to severe hypoxia was unchanged. ${ }^{16}$ It is more likely, therefore, that anemia develops once renal EPO formation is impaired, because the sensitivity of the liver towards hypoxia is less than that of the kidneys, so that erythropoiesis is maintained at a lowered set point. ${ }^{21}$ In fact, when EPO mRNA accumulation was investigated in rats exposed to graded degrees of hypoxic hypoxia or anemia, the contribution of the liver to the total EPO mRNA was lower under moderate than under severe stimulation. ${ }^{8}$

Although it would appear that the liver responds to anemic and hypoxic hypoxia in a principally similar manner to that of the kidneys, differences exist. Most importantly it was inferred from experiments with transgenic mice that different regulatory elements of the EPO gene may affect the oxygen-dependent response in these organs. ${ }^{22}$ Furthermore, a variety of external factors have been suggested to affect renal and hepatic EPO production differently. Interestingly in this respect, Beru et al. observed that cobalt, which consistently stimulates EPO mRNA accumulation in kidneys, induces hepatic EPO mRNA accumulation only in some, but not in all animals. ${ }^{23}$ Moreover, protein deprivation was reported to diminish EPO production in unoperated rats, ${ }^{24}$ but had no effect or the effect of increased EPO production in anephric rats. ${ }^{25.26}$ Conversely, androgens increase the rate of erythropoietin production in unoperated rats, ${ }^{27}$ but do not significantly change that of anephric ones. ${ }^{28}$ Finally, apart from systemic hypoxia, several types of hepatic injury have been reported to markedly stimulate EPO production by the liver. Thus, serum EPO levels in hypoxic bilaterally nephrectomized rats were found to be considerably higher following the induction of liver injury by either partial hepatectomy, administration of carbon tetrachloride, or ligation of the common bile duct. ${ }^{26,29}$ Similarly, hematocrit values in anephric patients have been reported to increase during episodes of hepatitis. ${ }^{30}$ It has been suggested that increased hepatic EPO formation under these conditions is related to regeneration of liver tissue, but further work will be required to define the cellular sites and mechanisms of this increased production.

\section{CELLULAR SITES OF EPO FORMATION IN THE LIVER}

The liver comprises a variety of different cell types that can be roughly subdivided into parenchymal cells (hepatocytes) and nonparenchymal cells (including Kupffer cells, endothelial cells, and connective tissue cells). Among these different cells, it has for a long time been suggested that both Kupffer cells and hepatocytes 
produce EPO. The evidence in favor of Kupffer cells includes correlations between reticuloendothelial hyperplasia and increased EPO production under certain experimental settings ${ }^{31}$ and the observation that Kupffer cells in the whole liver and in mixed liver cultures sequestered immunofluorescent antibodies raised against partially purified EPO. ${ }^{13,32}$ Furthermore, it was proposed that Kupffer cells in culture secrete EPO.$^{33}$ On the other hand, elevated levels of EPO were found in plasma, urine, and tumor extracts of hepatocellular carcinoma patients, ${ }^{34,35}$ and more recently two human hepatoma cell lines were reported to produce EPO in vitro (see below) ${ }^{36,37}$ Any conclusion from these findings, however, as to the physiological role of hepatocytes for EPO formation remained difficult, in particular because renal cell carcinomas, which are considered to be derived from renal tubular cells, have also been shown to express EPO ${ }^{38}$ whereas most of the available evidence indicates that EPO is normally produced by peritubular cells..$^{39-41}$

More definite evidence for the role of hepatocytes and other liver cells in EPO production has recently been obtained by in situ hybridization and cell fractionation experiments. Thus, using in situ hybridization, Koury et al. and Schuster et al. demonstrated that most of the cells expressing EPO mRNA in mouse or rat liver are in fact hepatocytes. ${ }^{42,43}$ However, about $20 \%$ of cells expressing EPO mRNA had a nonepithelial morphology and were located in or adjacent to the sinusoidal spaces, thus indicating that besides parenchymal cells at least one type of nonparenchymal liver cells also produces EPO. Similar conclusions were obtained from the measurement of EPO mRNA in isolated liver cells separated by different protocols, which also showed that EPO mRNA is normally present in both hepatocytes and nonparenchymal cells. Although somewhat variable results were reported as to whether the abundance of EPO mRNA per unit total RNA in nonparenchymal cells is lower, ${ }^{43}$ similar, ${ }^{44}$ or higher ${ }^{45}$ than in hepatocytes, two studies concluded that when quantitative differences in the content of total RNA per cell and the cell number per liver are considered, the nonparenchymal cells do not appear to contribute more than about 5\% to the total EPO mRNA in the liver of both hypoxic juvenile ${ }^{44}$ and anemic-hypoxic adult rats. ${ }^{43}$ Whether the relative contribution of both cell populations may vary under certain conditions, and if the nonparenchymal cells producing EPO are in fact Kupfer cells, remains to be clarified. Interestingly, in transgenic mice, showing oxygen-dependent expression of a human EPO transgene in liver, but not in kidneys, transgenic human EPO mRNA was expressed only in hepatocytes and not in nonparenchymal cells, suggesting that the expression of EPO in these cell types may be regulated differently. ${ }^{42}$

\section{IN VITRO MODELS FOR HEPATIC EPO FORMATION}

Tissue culture systems derived from liver cells have not only been used in attempts to identify the cells producing EPO but also to facilitate studies on the cellular mechanisms of the oxygen-dependent control of the hormone. In mixed fetal liver cell cultures an increased secretion of erythropoietic bioactivity has been observed upon reduction of the oxygen tension. ${ }^{46.47}$ These observations provided the first evidence that oxygen-sensing mechanisms can be retained in cultured liver cells, but the cell type responsible for this secretion and possible interactions of different cells were not identified. An alternative approach has been the study of EPO formation by the two human hepatoma cell lines HepG2 and Hep3B. Following the observation by Goldberg et al. that these cell lines 


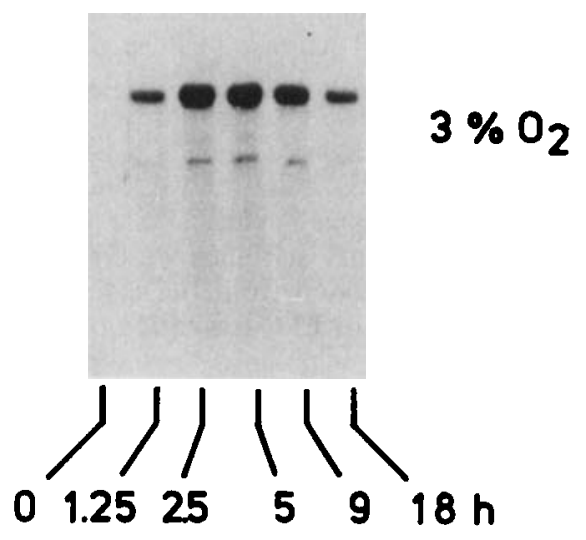

FIGURE 2. Autoradiograph of an RNase protection assay for EPO mRNA using total RNA $(100 \mu \mathrm{g})$ from isolated juvenile rat hepatocytes in primary culture. Hepatocytes were isolated by a two-stage in situ perfusion of the liver with chelating agents and collagenase..$^{50}$ Following isolation, cells were preincubated for 4 hours at $40 \%$ oxygen in medium containing $10 \%$ fetal calf serum. They were then refed serum-free culture medium and exposed to $3 \%$ oxygen for up to 18 hours. Note that reduction of the oxygen tension led to a time-dependent accumulation of EPO mRNA; no increase was observed in cultures maintained at $40 \%$ oxygen for identical time periods.

express EPO mRNA and secrete immuno- and bioreactive EPO in an oxygendependent fashion, ${ }^{37}$ these cells have been widely used for studies on the cellular signal transduction and the control of the EPO gene, and have thereby undoubtedly allowed major progress in EPO research. Nevertheless, because it is unknown if characteristics of EPO production by these cell lines are influenced by their malignant transformation, we felt that it remains desirable to study the production of EPO also in those cells that are physiologically producing the hormone in vivo. In view of the above-mentioned evidence that in juvenile rats hepatocytes are the primary site of EPO mRNA expression in vivo, we have therefore studied the expression of EPO mRNA in primary cultures of juvenile rat hepatocytes.

\section{EXPRESSION OF EPO MRNA IN ISOLATED HEPATOCYTES}

To assess the ability of isolated hepatocytes to modulate the expression of EPO in an oxygen-dependent fashion, hepatocytes were isolated from normoxic animals and incubated in vitro at different oxygen tensions. Immediately after isolation, cells were first incubated for 4 hours in the presence of $10 \%$ serum to allow cell attachment at ambient or elevated oxygen pressure $\left(20-40 \% \mathrm{O}_{2}\right)$. During this preincubation period average EPO mRNA concentrations in isolated hepatocytes remained either constant $\left(20 \% \mathrm{O}_{2}\right)$ or declined to very low levels $\left(40 \% \mathrm{O}_{2}\right)$. After the 4-hour period, cells were refed a serum-free medium, and when they were then exposed to low oxygen pressure $\left(3 \% \mathrm{O}_{2}\right)$, we found a time-dependent accumulation of EPO mRNA, as shown in FIGURE 2. By contrast, EPO mRNA levels remained low upon further exposure to $40 \%$ oxygen. The hypoxia-induced increase in EPO mRNA levels was detectable as early as 1.25 hours after changing 
the composition of the gas inflow to the incubators and reached maximal values between 2.5 and 5 hours. Thereafter EPO mRNA levels declined, but nevertheless remained elevated for at least 18 hours as compared to incubation at 20 or $40 \%$ oxygen. Thus the time course of EPO mRNA accumulation in isolated hepatocytes in vitro resembles that of hepatic EPO mRNA accumulation in vivo, where an initial peak is also followed by partial down-regulation, despite continued hypoxic exposure. ${ }^{8}$

Further experiments indicated that the hypoxia-induced rise in EPO mRNA levels in isolated hepatocytes is specific, because the rates of total RNA synthesis, as determined by $\left[{ }^{3} \mathrm{H}\right]$ uridine incorporation, decline with decreasing oxygen tension, as illustrated in FIGURE 3. Thus it appears possible that the level of EPO mRNA at a given oxygen tension results from a balance between specific expression of the EPO gene and nonspecific deterioration of cellular functions. This might explain why EPO mRNA concentrations in cells incubated at oxygen concen-
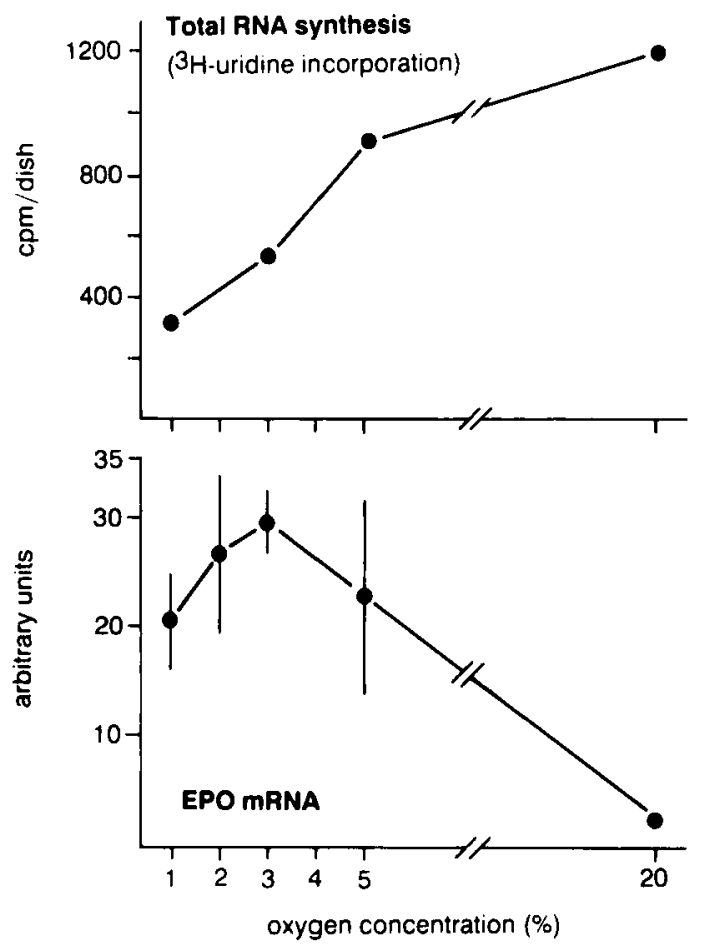

FIGURE 3. Rates of total RNA synthesis (upper panel) and accumulation of EPO mRNA (lower panel) in isolated juvenile rat hepatocytes. Following a 4-hour preincubation period (see legend of FIG. 2), cells were incubated for 18 hours at varying oxygen tensions. Rates of total RNA synthesis were determined by measurement of $\left[{ }^{3} \mathrm{H}\right]$ uridine incorporation into trichloroacetic acid-insoluble material during the final 2.5 hours of incubation. EPO mRNA was measured by RNase protection and is expressed in arbitrary units derived from the comparison with an external standard that was coanalyzed on each gel. EPO mRNA levels in cultures incubated at $1 \%$ and $2 \%$ oxygen were significantly lower than those in parallel cultures of the same cell preparation that were incubated at $3 \%$ oxygen. ${ }^{44}$ 


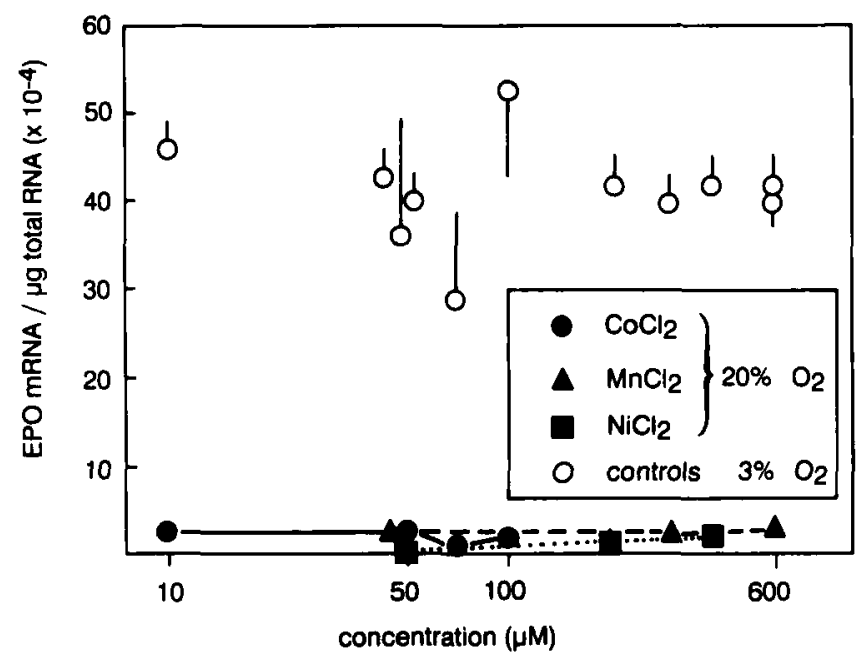

FIGURE 4. EPO mRNA accumulation in isolated juvenile rat hepatocytes incubated for 18 hours at $20 \%$ oxygen in the presence of $\mathrm{CoCl}_{2}, \mathrm{MnCl}_{2}$, and $\mathrm{NiCl}_{2}$ (closed symbols) and in parallel control cultures from the same cell preparations incubated at $3 \%$ oxygen in the absence of metals (open symbols). A slight, albeit significant increase in EPO mRNA as compared to cultures incubated at $20 \%$ oxygen in the absence of metals was seen with 50 $\mu \mathrm{M} \mathrm{CoCl}{ }_{2}$ and $400 \mu \mathrm{M} \mathrm{NiCl}_{2}$, but overall, no marked stimulation of EPO mRNA expression could be induced, whereas hypoxic exposure of cells consistently increased EPO mRNA levels. EPO mRNA was measured by RNase protection and is expressed in arbitrary units derived from comparison with an external standard (values are means \pm SE from independent experiments, $\mathrm{n}=4$ for $50 \mu \mathrm{M} \mathrm{CoCl}_{2}$ and 3 for all other points). ${ }^{44}$

trations below $3 \%$ were slightly reduced. Independent of the quantitative relationship between oxygen availability and EPO mRNA levels, the EPO mRNA response to a reduction in oxygen tension clearly indicates that regulation of EPO production can occur by way of intrinsic oxygen-sensing mechanisms, and does not essentially depend on external signals or intact tissue structure, although both may modulate the expression in vivo. That hepatocytes are able to directly sense the oxygen tension is in accordance with the results of in situ hybridization experiments, which showed preferential expression of EPO mRNA in perivenous hepatocytes of the liver lobule, that is, those areas where local oxygen tensions are lowest.

Besides hypoxia, certain divalent metals such as $\mathrm{CoCl}, \mathrm{MnCl}$, or $\mathrm{NiCl}$ have been shown to stimulate EPO production in vivo and in hepatoma cells. Based on a series of elegant experiments in Hep3B cells, Goldberg et al. have proposed that this stimulation might occur by way of replacement of a central iron atom in a putative heme protein operating as the oxygen sensor molecule, so that the incorporation of these metals mimicks a deoxyconfirmation of this heme protein. ${ }^{48}$ In view of this hypothesis, we have investigated the effect of $\mathrm{CoCl}, \mathrm{NiCl}$, and $\mathrm{MnCl}$ on EPO mRNA levels in isolated hepatocytes incubated at ambient oxygen pressure for 18 hours. However, as illustrated in Figure 4, addition of these metals did not lead to a major increase of EPO mRNA levels. A slight, albeit significant elevation, compared to parallel cultures incubated at $20 \% \mathrm{O}_{2}$ in the 
absence of metals, was observed with $50 \mu \mathrm{M} \mathrm{CoCl}$ and $400 \mu \mathrm{M} \mathrm{NiCl}$, but in neither case did the EPO mRNA concentrations exceed $7 \%$ of the concentration in parallel cultures incubated at low oxygen pressure $\left(3 \% \mathrm{O}_{2}\right)$. The failure of $\mathrm{CoCl}$ to stimulate EPO expression more markedly in isolated hepatocytes is in accordance with previous studies in mixed fetal liver cells, in which hypoxia, but not $\mathrm{CoCl}$, stimulated EPO production, ${ }^{46}$ and with experiments performed in vivo, in which cobalt was a less consistent stimulus of hepatic EPO mRNA accumulation than hypoxia. ${ }^{23}$ One reason for the inconsistent effect of divalent metals on the expression of EPO may be that the turnover rate of a putative heme protein is variable, depending on the model investigated. Thus it appears possible that in isolated hepatocytes the turnover rate is significantly lower than in hepatoma cells, so that no efficient incorporation of divalent metals occurs. On the other hand we have no positive evidence at present that the oxygen sensing that governs the expression of EPO in hepatocytes occurs by way of a heme molecule.

Independent of how changes in the oxygen availability of hepatocytes are

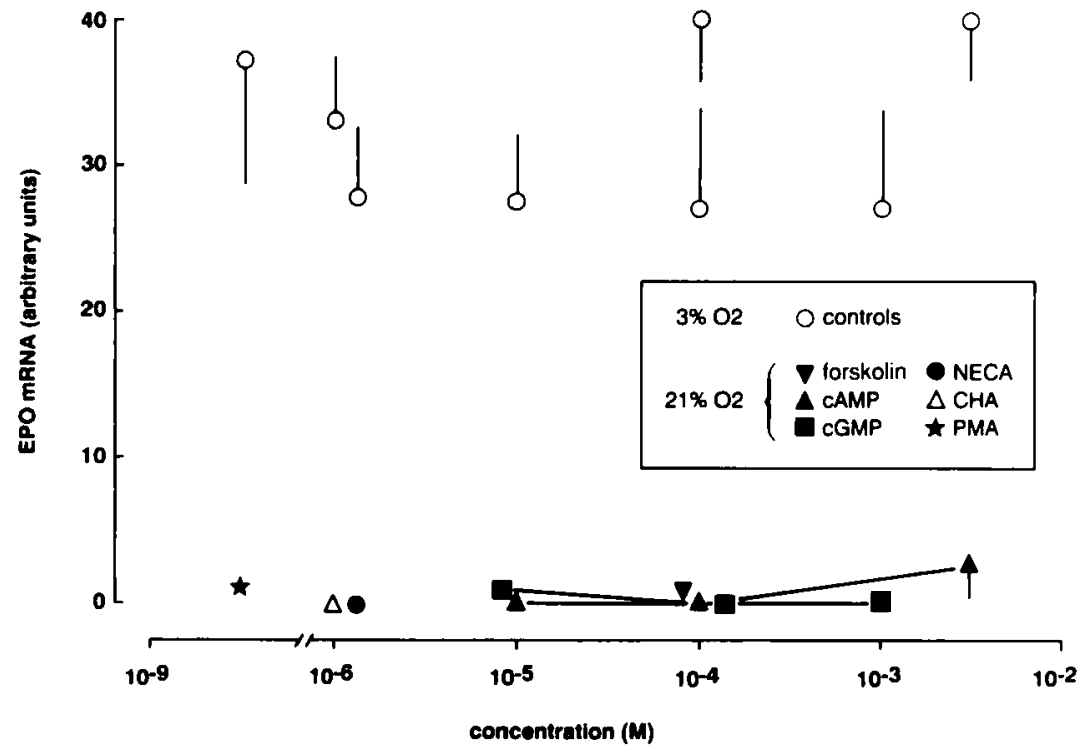

FIGURE 5. EPO mRNA accumulation in isolated juvenile rat hepatocytes incubated for 18 hours at $20 \%$ oxygen in the presence of "second messengers" or agonists (closed symbols) and in parallel control cultures from the same preparation incubated at $3 \%$ oxygen in the absence of agents. The substances tested were (a) permeable analogues of cAMP and cGMP; (b) forskolin, which was used to stimulate adenylate cyclase; (c) 5 - $N$-ethylcarboxyamidoadenosine (NECA) or $N$-cyclohexyladenosine (CHA), which was used to stimulate adenosine receptors ( $A 1$ and $A 2$, respectively); and (d) phorbol 12-myristate 13-acetate (PMA), which was used to stimulate protein kinase $C$. None of the substances tested led to a significant increase of EPO mRNA levels as compared to parallel cultures incubated at $20 \%$ oxygen in the absence of agents. EPO mRNA was measured by RNase protection and is expressed in arbitrary units derived from comparison with an external standard (values are mean $\pm S E$ from independent experiments, $n=3)^{44}$ 
sensed, the question arises as to how the signal emerging from a putative sensor molecule is transduced into a rise of EPO mRNA. In other experimental models, such as mixed fetal liver cells, for example, the cAMP pathway has been suggested to mediate the induction of EPO expression. ${ }^{46,49} \mathrm{We}$ have therefore tested whether the rise in EPO in isolated hepatocytes that occurs upon hypoxic incubation could be mimicked by activation of classical second messenger pathways. To this end, hepatocytes were incubated at ambient oxygen pressure in the presence of membrane-permeable analogues of cAMP and cGMP, in the presence of two adenosine receptor agonists, or in the presence of the phorbol ester PMA, which was used to stimulate protein kinase C. As illustrated in FIgure 5, however, addition of none of these substances led to a significant increase of EPO mRNA levels.

\section{SUMMARY}

Several lines of evidence indicate that the liver is the predominant production site for EPO during the early stages of development. Moreover, in adults, it may contribute significantly to EPO production in some species. Independent of age hepatocytes are the major cellular sites of EPO gene expression in the liver, but quantitatively less significant expression also occurs in at least one additional type of nonparenchymal cell. Although some indirect evidence suggests that these nonparenchymal cells producing EPO may be Kupffer cells, their identity remains to be clarified.

Regarding the mechanisms of the adaptation of hepatic EPO production to changes in oxygen availability in the organism, experiments with isolated perfused livers, mixed liver cell cultures, hepatoma cells, and, more recently, isolated hepatocytes have provided evidence that inherent cellular oxygen-sensing mechanisms exist and that external factors are not essential. The use of hepatoma cells has allowed investigation of these cellular mechanisms of oxygen-dependent gene control, and further studies in nontransformed hepatocytes may complement these studies.

\section{REFERENCES}

1. Jacobson, L. O., E. Goldwasser, W. Fried \& L. Plzak. 1957. Role of the kidney in erythropoiesis. Nature 179: 633-634.

2. Mirand, E. A. \& T. C. Prentice. 1957. Presence of plasma erythropoietin in hypoxic rats with or without kidney(s) and/or spleen. Proc. Soc. Exp. Biol. Med. 96: 49-51.

3. NaETS, J. P. \& M. WitTEK. 1968. Presence of erythropoietin in the plasma of one anephric patient. Blood 31: 249-251.

4. Carmena, A. O., D. Howard \& F. Stohlman. 1968. Regulation of erythropoiesis XXII. Erythropoietin production in the newborn animal. Blood 32: 376-382.

5. Zanjani, E. D., J. Poster, H. Burlington, L. I. Mann \& L. R. Wasserman. 1977. Liver as the primary site of erythropoietin formation in the fetus. J. Lab. Clin. Med. 89: $640-644$.

6. FRIED, W. 1972. The liver as a source of extrarenal erythropoietin production. Blood 40: $671-677$.

7. Erslev, A. J., J. Caro, R. Kansu \& R. Silver. 1980. Renal and extrarenal erythropoietin production in anaemic rats. Br. J. Haematol. 45: 65-72.

8. TAN, C. C., K.-U. ECKardT, J. FirTh \& P. J. RatClifFe. 1992. Feedback modulation 
of renal and hepatic erythropoietin messenger RNA in response to graded anemia and hypoxia. Am. J. Physiol. 263: F474-F481.

9. Burke, W. T. \& B. S. MorSE. 1962. Studies on the production and metabolism of erythropoietin in rat liver and kidney. In Erythropoiesis. L. O. Jacobson \& M. Doyle, Eds.: 111-119. Grune \& Stratton, New York.

10. Zanjani, E. D., J. L. Ascensao, P. B. McGlave, M. Banisadre \& R. C. Ash. 1981. Studies on the liver to kidney switch of erythropoietin production. J. Clin. Invest. 76: $1183-1188$.

11. Schooley, J. C. \& L. J. MahlmanN. 1972. Erythropoietin production in the anephric rat. I. Relationship between nephrectomy, time of hypoxic exposure, and erythropoietin production. Blood 39: 31-38.

12. WANG, F. \& W. Fried. 1972. Renal and extrarenal erythropoietin production in male and female rats of various ages. J. Lab. Clin. Med. 79: 181-186.

13. Gruber, D. F., J. R. Zucali, J. Wleklinski, V. Larussa \& E. A. Mirand. 1977. Temporal transition in the site of rat erythropoietin production. Exp. Hematol. 5: $399-407$.

14. Koury, M. J., M. C. Bondurant, S. E. Graber \& S. T. Sawyer. 1988. Erythropoietin messenger RNA levels in developing mice and transfer of ${ }^{125}$ I-erythropoietin by the placenta. J. Clin. Invest. 82: 154-159.

15. Eckardt, K.-U., P. J. Ratcliffe, C. C. Tan, C. Bauer \& A. Kurtz. 1992. Age dependent expression of the erythropoietin gene in rat liver and kidneys. J. Clin. Invest. 89: 753-760.

16. TAN, C. C., K.-U. ECKardt \& P. J. RatClifFe. 1991. Organ distribution of erythropoietin messenger RNA in normal and uremic rats. Kidney Int. 40: 69-76.

17. EschвасH, J. W. 1989. The anemia of chronic renal failure: pathophysiology and the effects of recombinant erythropoietin. Kidney Int. 35: 134-148.

18. Chandra, M., G. K. Clemons \& M. McVicar. 1988. Relation of serum erythropoietin levels to renal excretory function: Evidence for lowered set point for erythropoietin production in chronic renal failure. J. Pediatr. 113: 1015-1021.

19. Blumberg, A., H. Keller \& H. R. Marti. 1973. Effect of altitude on erythropoiesis and oxygen affinity in anaemic patients on maintenance dialysis. Eur. J. Clin. Invest. 3: 93-97.

20. Fisher, J. W., W. J. Stuckey, D. D. Lindholm \& S. Abshire. 1971. Extrarenal erythropoietin production. Isr. J. Med. Sci. 7: 991-994.

21. Nathan, D. G., E. Schupak \& F. Stohlman. 1964. Erythropoiesis in anephric man. J. Clin. Invest. 43: 2158-2164.

22. Semenza, G. L., M. K. Nejfelt, S. M. Chi \& S. E. Antonarakis. 1991. Hypoxiainducible nuclear factors bind to an enhancer element located $3^{\prime}$ to the human erythropoietin gene. Proc. Natl. Acad. Sci. USA 88: 5680-5684.

23. Beru, N., J. McDonald, C. Lacombe \& E. Goldwasser. 1986. Expression of the erythropoietin gene. Mol. Cell. Biol. 6: 2571-2575.

24. Reissman, K. R. 1964. Protein metabolism and erythropoiesis. II. Erythropoietin responsiveness and erythropoietin formation in protein deprived rats. Blood 23: $146-153$.

25. Anagnostou, A., S. Schade \& W. Fried. 1978. Effect of protein deprivation on extrarenal erythropoietin production. Blood 51: 549-553.

26. Fried, W., J. BARONE-VARELAS \& C. MoRLEY. 1984. Factors that regulate extrarenal erythropoietin production. Blood Cells 10: 287-304.

27. Gordon, A. S., E. A. Mirand, J. Wenig, R. Katz \& E. D. Zanjani. 1968. Androgen actions on erythropoiesis. Ann. N.Y. Acad. Sci. 149: 318-335.

28. FrIED, W. \& T. KILBRIDGE. 1969. Effects of testosterone and cobalt on erythropoietin production. J. Lab. Clin. Med. 74: 623-629.

29. Naughton, B. A., S. M. Kaplan, M. Roy, A. J. Burdowski, A. S. Gordon \& S. J. PILIERo. 1977. Hepatic regeneration and erythropoietin production in the rat. Science 196: 301-302.

30. Kolk-Vegter, A. J., E. Bosch \& A. M. Van Leeuwen, 1971. Influence of serum hepatitis on haemoglobin level in patients on regular hemodialysis. Lancet ii: 526-528. 
31. Peschle, C., G. Marone, A. Genovese, I. A. Rappaport \& M. Condorelli. 1976. Increased erythropoietin production in anephric rats with hyperplasia of the reticuloendothelial system induced by colloidal carbon or zymosan. Blood 47: 325337.

32. Gruber, D. F., J. R. Zucali \& E. A. Mirand. 1977. Identification of erythropoietin producing cells in fetal mouse liver cultures. Exp. Hematol. 5: 392-398.

33. Paul, P., S. A. Rothmann, J. T. McMahon \& A. S. Gordon. 1984. Erythropoietin secretion by isolated rat Kupffer cells. Exp. Hematol. 12: 825-830.

34. Mirand, E. A. \& G. P. MuRPhy. 1971. Erythropoietin alterations in human liver disease. N.Y. State J. Med. 71: 860-863.

35. KEW, M. \& J. W. Fisher. 1986. Serum erythropoietin concentrations in patients with hepatocellular carcinoma. Cancer 58: 2485-2488.

36. Nielsen, O. J., S. J. Schuster, R. Kaufman, A. J. Erslev \& J. Caro. 1987. Regulation of erythropoietin production in a human hepatoblastoma cell line. Blood 70: 1904-1909.

37. Goldberg, M. A., G. A. Glass, J. M. Cunningham \& H. F. Bunn. 1987. The regulated expression of erythropoietin by two human hepatoma cell lines. Proc. Natl. Acad. Sci. USA 84: 7972-7976.

38. Da Silva, J.-L., C. Lacombe, P. Bruneval, N. Casadevall, M. Leporrier, J.-P. Camilleri, J. Bariety, P. Tambourin \& B. VARET. 1990. Tumor cells are the site of erythropoietin synthesis in human renal cancers associated with polycythemia. Blood 75: 577-582.

39. Lacombe, C., J.-L. Da Silva, P. Bruneval, J.-G. Fournier, F. Wendling, N. Casadevall, J.-P. Camilleri, J. Bariety, B. Varet \& P. Tambourin. 1988. Peritubular cells are the site of erythropoietin synthesis in the murine hypoxic kidney. J. Clin. Invest. 81: 620-623.

40. Koury, S. T., M. C. Bondurant \& M. J. Koury. 1988. Localization of erythropoietin synthesizing cells in murine kidneys by in situ hybridization. Blood 71: 524527.

41. Bachmann, S., M. Le Hir \& K.-U. Eckardt, 1993. Colocalization of erythropoietin mRNA and ecto-5'-nucleotidase immunoreactivity in peritubular cells of rat renal cortex indicates that fibroblasts produce erythropoietin. J. Histochem. Cytochem. 41: 335-341.

42. Koury, S. T., M. C. Bondurant, M. J. Koury \& G. L. Semenza. 1991. Localization of cells producing erythropoietin in murine liver by in situ hybridization. Blood 77: 2497-2503.

43. Schuster, S. J., S. T. Koury, M. Bohrer, S. Salceda \& J. Caro. 1992. Cellular sites of extrarenal and renal erythropoietin production in anemic rats. Br. J. Haematol. 81: 153-159.

44. Eckardt, K.-U., C. W. Pugh, P. J. Ratcliffe \& A. Kurtz. 1993. Oxygen dependent modulation of erythropoietin mRNA in rat hepatocytes in vitro. Pfluegers Arch. In press.

45. Lacombe, C., J.-L. Da Silva, P. Bruneval, C. Chesne, A. Guillouza, J.-P. Camilleri, J. Bariety, B. Varet \& P. Tambourin. 1991. Expression of the erythropoietin gene in the kidney and the liver of the anaemic mouse. In Response and Adaptation to Hypoxia: organ to organelle. S. Lahiri, N. S. Cherniack \& R. S. Fitzgerald, Eds.: 69-77. Oxford University Press.

46. Kurtz, A., W. Jelkmann, A. Pfuhl, K. Malmstrom \& C. Bauer. 1986. Erythropoietin production by fetal mouse liver cells in response to hypoxia and adenylate cyclase stimulation. Endocrinology 118: 567-572.

47. ZUCALI, J. R. 1980. Fetal liver cell conditioned media as a source of erythropoietic stimulating activities. Exp. Hematol. 8 (Suppl 8): 103.

48. Goldberg, M. A., S. P. DUNNing \& H. F. BUNN. 1988. Regulation of the erythropoietin gene: evidence that the oxygen sensor is a heme protein. Science 242: 1412-1415.

49. Fisher, J. W. 1988. Pharmacologic modulation of erythropoietin production. Annu. Rev. Pharmacol. \& Toxicol. 28: 101-122.

50. Berry, M. N., \& D. S. FrIEND. 1969. High-yield preparation of isolated rat liver parenchymal cells: a biochemical and fine structure study. J. Cell Biol. 43: 506-520. 


\section{DISCUSSION OF THE PAPER}

JaIme CARo (Thomas Jefferson University, Philadelphia, PA): Did you inject any animals of the same age and size as the animals from which you obtained hepatic cells for culture with cobalt, and did you see any induction?

K.-U. ECKARDT (University of Regensburg, Regensburg, Germany): We haven't studied this systematically so far. Your question is important because there is some evidence from Dr. Goldwasser's group that cobalt does not provide a consistent stimulus for hepatic erythropoietin mRNA accumulation. We have done a few animals, and we have seen an induction, but we haven't quantified it exactly. So I don't know whether the stimulation is a consistent phenomenon.

Chairman Eugene Goldwasser (The University of Chicago, Chicago, IL): Wouldn't it be better in trying to determine the specificity of the inhibitors of PKC or of protein kinases to use poly A plus RNA rather than total RNA? I ask this because you may be having a differential effect on message transcription, and all the ribosomal RNA in there will bias it.

ECKARDT: Yes, this might be a very good suggestion. Clearly the specificity of such components is very difficult to determine. I think that the measurement of total RNA synthesis is a good parameter for assessing totally unspecific effects on cellular function. Nevertheless, with this kind of study we can only try to point to mechanisms that may be important, and that may either be only a very small link, or may be one of the central events. To figure this out with whole cell experiments, of course, is very difficult.

JOACHIM FANDREY (University of Bonn, Bonn, Germany): We have had this discussion on the different effects of protein kinase $\mathrm{C}$ activators several times, and clearly these cells have a biphasic response. It would be very interesting to look at EPO mRNA levels at very early time points by competitive PCR. We have done this, looking at treatment with phorbol esters for 30 minutes and for one hour, and there is definitely no inhibition of erythropoietin production. We have used other stimuli, such as cytokines, and we saw inhibition within one hour. So I think that maybe these liver cells and HepG2 cells are different. With respect to the TPA response, we see the inhibition there at three hours.

My question is regarding the cells. You showed this nice induction where you had two hypoxic periods, one after another. You showed that the response in the second one was lower. Have you tried to keep the cells in normoxia for 25 hours, which you needed for the first period, and then stimulated them? Is the lower response specific for the second stimulus, or is it because the cells are just older in culture?

ECKARDT: Let me start with your second question. I'm not sure whether I understood you. What I showed on the first slide is that after a short period of 2-5 hours there is a marked induction, and then under continuous hypoxic exposure the levels come down. What we did then in the next step, using the same conditions, was that we just interrupted the hypoxic exposure and then re-exposed the cells to hypoxia. There was a second increase under this situation. The peak was not as high as immediately after the beginning, but, again, definitely the cells increased the EPO messenger RNA.

FANDREY: My question was, If you keep the cells normoxic for the same time period that you used for your first induction and then expose them to hypoxia, will they show the full response, or is the response lower? 
ECKARDT: The response is not just as high as immediately after the isolation, but it is almost as high. Coming back to your first question regarding the kinetics with PMA, we have also done time course studies, at short intervals. We see a reduction of the erythropoietin messenger RNA at very short intervals, for example, after 1 hour. As you mentioned, I think this simply tells us that there are differences that may be important between hepatocyte primary cultures and hepatoma cells.

H. Franklin BunN (Brigham and Women's Hospital, Boston, MA): I did not understand from the last diagram you presented what evidence you had that protein kinase $\mathrm{C}$ is involved in the hypoxic induction of EPO.

ECKARDT: It is indirect insofar that inhibition of kinase activity with several kinase inhibitors abrogates the response.

IVAN N. RICH (University of Ulm, Ulm, Germany): I have two simple questions with respect to the methodology. You mentioned at the beginning that one can separate hepatocytes by differential centrifugation. What is the level of contamination in the hepatocyte population, and how long can you keep them in culture? Is there any proliferation in these cultures?

ECKARDT: There is no proliferation under the conditions we are using. As you know, it is very difficult to get isolated hepatocytes to proliferate, and we haven't made any attempts in this direction because we were interested in establishing conditions for the study of freshly isolated cells after a short interval without adding any further complexity to the system by inducing cell proliferation and things like that. So under these conditions the cells are not growing, and I should add in this context that we are using serum-free conditions. During the first four hours the cells are incubated in the presence of serum to allow them to attach, but thereafter we use serum-free culture medium to study the expression of erythropoietin. With regard to the contamination, clearly using differential centrifugation, we have some contamination, but the contamination under the conditions that we are using, with low speed centrifugation and other conditions of cell harvesting, I would say is no more than 5 percent.

MARK J. KOURY (Vanderbilt University, Nashville, TN): I have a question about the decline in erythropoietin RNA levels in the primary hepatocytes. You mentioned that there was a decline generally in mRNA. Did you look at specific messages of other genes, not just the decline in RNA?

ECKARDT: We have looked at actin, but this may not be a very good choice because it is extremely stable.

KouRY: It has a long half-life.

ECKARDT: Yes, and this clearly does not change.

Koury: The other thing about this is that you use $3 \%$ oxygen, which is a level that would not induce much erythropoietin in Hep3B or HepG2 cells. Is that correct?

ECKARDT: I have not done a comparison between hepatoma cells and hepatocytes. Most people are using somewhat lower concentrations, and with $1 \%$ we do also get a response, but it is not as good as with 3 percent.

Koury: This all leads to the question, in my mind at least, about whether primary cells are correct as an in vivo representation. Do you think that there is a situation in which cells are producing EPO for only a short period of time and then that area is relieved of the hypoxia so that the cells are coming on and off in much the same way as Christmas tree lights come on and off. If that is so, then you must be into some very complex layers of control. I was wondering if you agree with this?

ECKARDT: Yes, clearly this is an important consideration. You could argue 
that although in the primary culture we have freshly isolated cells of a more or less homogeneous population, only some of these cells may produce erythropoietin when we look at them. I can't exclude that possibility.

WolfGang E. B. JelkmanN (University of Bonn, Bonn, Germany): One difference from the established hepatoma cell lines is that your preparation is not pure. Now if there are any macrophages in your preparations, substances like phorbol ester may induce production of interleukin-1, TNF, and reactive oxygen species. These products may lead to the inhibition of EPO production.

EcKARDT: Yes, I can only agree with you. I mean that is a problem one cannot absolutely circumvent. As I said, we are using conditions that are very well established, which everybody uses to study hepatocytes in culture, which is a more or less pure culture, but still you may argue that a very few cells may have some effect in this context. With regard to the PMA effect, we have also studied it being aware of data presented by your group and other groups, showing that interleukin-1 beta influences the expression, but we have not seen an effect on these isolated hepatocytes. So I am not very worried that the PMA effect is due to an interaction with other cells.

Franklin H. EPSTEIn (Harvard Medical School, Boston, MA): The question of possible contamination might be answered if you did in situ hybridization, because most of the cells that were clearly hepatocytes might show the mRNA for EPO. I wonder whether, in fact, you have done that using these separated cell populations?

ECKARDT: I think what you are addressing is whether the cells that we are studying and that show accumulation of erythropoietin mRNA in the dish are hepatocytes. I am pretty sure they are, because if we use conditions where there are more nonparenchymal cells, if we use a nonseparated cell preparation, the signal is absolutely identical to those obtained with a separated cell preparation. 